\title{
Pusat Seni Pertunjukan Dengan Pendekatan Eko Kultural Di SURAKARTA
}

\author{
Muhammad Faruq Rizky Ardianto, Hardiyati, Agus Heru Purnomo \\ Program Studi Arsitektur \\ Jurusan Arsitektur Fakultas Teknik \\ Universitas Sebelas Maret Surakarta \\ Email : faruq.rizky@gmail.com
}

\begin{abstract}
Along the time, the performing art is not just a mere entertainment but also as a necessity for the modern man. Surakarta is the city with the development of the cultural and artistic performances' development, starting from kethoprak, wayang and keroncong that develops and be born in this city. The problem of the design is to create a character from EcoCultural element of Javanese culture and environment friendly, to the performing arts building. The problem of the design is how to achieve a performance art in accordance with the changing times which does not leave the local cultural elements. The design method used is the method of approach in order to create a container Eco Cultural arts activities that are capable of adapting to the changing times but still consider the local culture and environment friendly. Results obtained in the form of design cultured Center for the Performing Arts and as an application of environmentally friendly Eco Cultural character. Building Performing Arts Center is expected as container performing arts activities in Surakarta.
\end{abstract}

Keywords: Eco Cultural, Performance Art

\section{PENDAHULUAN}

Seiring perkembangan jaman, seni pertunjukan juga mengalami perkembangan yang cukup pesat. Seni pertunjukan saat ini tidak hanya menjadi sebuah hiburan semata, namun juga menjadi sebuah kebutuhan. Timbulnya hasrat dan ketertarikan manusia untuk menyaksikan pertunjukan yang dipergelarkan oleh orang lain, serta keinginan dari para seniman untuk disaksikan dan mempertunjukkan hasil karya mereka, telah dirasakan sebagai kebutuhan naluri dan spiritual bagi masyarakat modern yang beradab dan berbudaya. Oleh adanya tuntutan tersebut, maka diperlukan suatu wadah untuk menampung kegiatan seni pertunjukan.

Menurut Sedyawati, pertunjukan adalah segala ungkapan seni yang substansi dasarnya pergelaran langsung di hadapan penonton yang dilakukan seseorang didepan orang lain dan mempunyai pengaruh terhadap orang tersebut (Sedyawati, 2009).

Perkembangan seni pertunjukan di Indonesia dipengaruhi oleh bangsa India, kemudian budaya Islam, dan terakhir dari Eropa. Masing-masing telah memberikan sumbangan terhadap perkembangan seni pertunjukan di Indonesia. Pengaruh budaya India mendorong perkembangan keindahan dalam seni tari dan drama, pengaruh budaya Islam memperkenalkan gagasan berbaris dalam tari serta rampak gendang; dan Eropa membawa drama modern atau drama tanpa musik dan tari (Edi Sedyawati, 2002:1-2). Beberapa kota di Indonesia memberikan sumbangsih terhadap perkembangan seni pertunjukan, salah satunya adalah Kota Surakarta. Kota Surakarta sendiri memiliki beberapa potensi di bidang seni pertunjukan. Kota Surakarta dari dulu hingga sekarang diketahui mempunyai seni pertunjukan yang menarik dan terkenal, yang akhirnya tumbuh dan berkembang. Beberapa kesenian pertunjukan yang tumbuh dan berkembang di kota ini seperti Srimulat, wayang orang yang di pentaskan di Gedung Wayang Orang Sriwedari, seni tari, seni musik orkes humor, musik keroncong, Solo Ethnic Music sebagai pertunjukan kesenian musik etnik serta Solo Performing Arts sebagai pertunjukan kesenian kontemporer. 
Seni pertunjukan di Surakarta berkembang cukup baik dengan sering diadakanya kegiatan pertunjukan seni dan budaya yang digelar. Kegiatan ini banyak menarik masyarakat dan wisatawan untuk ikut berpartisipasi, hal tersebut dapat dilihat dari jumlah wisatawan, penonton dan seniman yang bertambah dari tahun ke tahun.

Faktor lain yang mempengaruhi perkembangan seni pertunjukan dan budaya adalah adanya globalisasi. Era globalisasi saat ini, kebudayaan luar bebas masuk ke Indonesia melalui beberapa media komunikasi dan informasi seperti buku, televisi dan internet. Fenomena tersebut dapat mengikis atau menyebabkan punahnya warisan kebudayaan Indonesia khususnya kesenian tradisional Jawa oleh kesenian modern jika terjadi kesalahan dalam pemaknaan globalisasi dan modernisasi. Dari peristiwa tersebut, jika kesenian tradisional tidak di kemas dan di wadahi secara lebih menarik, bukan tidak mungkin kesenian Jawa akan terkikis oleh kesenian modern yang lebih di minati oleh anak muda sekarang.

Fenomena - fenomena tersebut menjadi latar belakang perencanaan pusat seni pertunjukan di Surakarta sebagai wadah seni pertunjukan di Kota Surakarta yang di dalamnya terdapat kegiatan pagelaran seni pertunjukan, kegiatan pelatihan dan kegiatan rekreasi. Pusat seni pertunjukan tersebut di peruntukkan bagi pelaku seni pertunjukan yang membutuhkan ruang untuk berkesenian, masyarakat yang tertarik mempelajari seni, komunitas seni pertunjukan yang ingin bersosialisasi dan mengadakan berbagai acara kesenian, serta masyarakat umum yang mencari hiburan.

Adanya perkembangan seni pertunjukan di Surakarta melalui sarana dan prasarana yang lebih baik serta wadah yang representatif, akan mendorong masyarakat menikmati karya seni yang beragam dan penuh makna. Diharapkan dengan adanya Pusat Pertunjukan Seni Pertunjukan ini mampu menarik minat masyarakat untuk lebih menghargai dan menikmati kembali kesenian daerah yang makin lama makin tergerus oleh modernisasi.

\section{METODE}

\subsection{Metode Pengumpulan Data}

Yang berisi :

1. Studi Literatur, melakukan studi dengan jalan mencari, membaca, dan mencerna isi buku yang sesuai dengan tema kajian sehingga di peroleh data yang valid dan sesuai.

2. Preseden, yaitu menambah informasi berupa kajian pembanding atau preseden yang dapat dijadikan acuan. Studi ini dilakukan dengan mengeksplorasi contoh-contoh objek sejenis sehingga dapat dijadikan perbandingan.

3. Observasi/ survey, survey ke lokasi tapak untuk mengetahui dan mengamati kondisi tapak yang aktual.

\subsection{Metode Analisa Data}

Tahap analisa data merupakan proses pengolahan data dari semua informasi yang telah didapatkan pada tahap sebelumnya dan merangkum hasil pengolahan data pada setiap akhir pembahasan. Proses analisis data terdapat 3 langkah pemograman, yakni:

1. Pemograman Fungsional

Pemrograman fungsional merupakan penerjemahan pengguna dan kegiatan yang diwadahi secara terstruktur. Tahapan ini ditujukan untuk mengidentifikasi pengguna dan alur kegiatan secara skematik.

2. Pemograman Perfomansi

Pemrograman performansi merupakan pendekatan sistem fungsi dari wadah arsitektur sehingga ditemukan persyaratan karakteristik respon desain.

3. Pemograman Arsitektur

Pemrograman arsitektur merupakan penerjemahan analisis berdasarkan efektifitas fungsi dan persyaratan performansi secara arsitektural ke dalam spesifikasi bangunan yang akan dirancang.

\subsection{Metode Sintesis}

Sintesis merupakan proses perangkaian tiap-tiap bagian yang terpisah agar membentuk suatu konsep yang utuh dan terdeskripsi dengan baik. Pada tahap ini, hasil dari pemograman pada tahap analisis diolah untuk mencari kesimpulan 
sebagai upaya mendapatkan pendekatan konsep perencanaan dan perancangan yang sesuai.

\subsection{Konsep Perencanaan dan Perancangan}

Dari proses analisis dan sintesa arsitektural akan dihasilkan beberapa konsep berupa konsep lokasi, konsep peruangan, konsep tampilan bangunan, konsep utilitas dan struktur bangunan yang disebut sebagai konsep Perencanaan dan Perancangan Pusat Seni Pertunjukan di Surakarta.

\section{ANALISIS}

\subsection{Analisis Pelaku dan Kegiatan}

1. Kegiatan Seni Pertunjukan a. Seni Kontemporer

1) Artis/Seniman/Penyaji

2) Staff Seni Kontemporer

3) Penata Suara

4) Penata Cahaya

5) Penata Panggung

b. Seni Musik

1) Artis/Seniman/Penyaji

2) Staff Seni Musik

3) Penata Suara

4) Penata Cahaya

5) Penata Panggung

c. Seni Daerah

1) Artis/Seniman/Penyaji

2) Staff Seni Kontemporer

3) Penata Suara

4) Penata Cahaya

5) Penata Panggung

2. Kegiatan Edukasi
a. Pengunjung
b. Murid
c. Staff Pengajar
d. Staff Administrasi

3. Kegiatan Rekreasi
a. Pengunjung
b. Komunitas Seni
c. Pengelola

4. Kegiatan Penunjang
a. Pengunjung
b. Penjual makanan dan minuman
c. Penjual souvenir

5. Kegiatan Pengelola

a. Direksi

1) Direktur

2) Wakil Direktur

3) Sekretaris b. Operasional Kegiatan

1) Bagian Keuangan \& Administrasi

2) Bagian Pemasaran

3) Bagian Pertunjukan

4) Bagian Operasional Gedung \& Peralatan

5) Bagian Pendidikan dan Pelatihan

6. Kegiatan Servis
a. Cleaning Service
b. Office Boy
c. Operasional Gedung
1) Bagian Utilitas
2) Bagian Mechanical Electrical
3) Bagian Keamanan
4) Bagian Perawatan

\subsection{Analisis Besaran Ruang}

Berdasarkan hasil kebutuhan perhitungan kapasitas dan analisis kegiatan, maka diperoleh besaran ruang dari masing - masing kelompok fungsi ruang sebagai berikut.

Tabel 1. Rekapitulasi Kebutuhan Ruang

\begin{tabular}{|l|l|l|}
\hline No & \multicolumn{1}{|c|}{ Kelompok Ruang } & Besaran Ruang \\
\hline 1 & Kegiatan penerima & $3605,13 \mathrm{~m}^{2}$ \\
\hline 2 & $\begin{array}{l}\text { Kegiatan seni } \\
\text { pertunjukan }\end{array}$ & $4852,83 \mathrm{~m}^{2}$ \\
\hline 3 & $\begin{array}{l}\text { Kegiatan pendidikan } \\
\text { dan pelatihan }\end{array}$ & $2139,85 \mathrm{~m}^{2}$ \\
\hline 4 & Kegiatan rekreasi & $1728 \mathrm{~m}^{2}$ \\
\hline 5 & Kegiatan penunjang & $436,36 \mathrm{~m}^{2}$ \\
\hline 6 & $\begin{array}{l}\text { Kegiatan } \\
\text { pengelolaan }\end{array}$ & $235 \mathrm{~m}^{2}$ \\
\hline 7 & \begin{tabular}{l} 
Kegiatan servis \\
\multicolumn{2}{|c|}{ TOTAL }
\end{tabular} & $1359,75 \mathrm{~m}^{2}$ \\
\hline
\end{tabular}

\subsection{Analisa Pemilihan Lokasi}

Berikut kriteria yang di gunakan dalam analisa pemilihan lokasi :

1. Kondisi peruntukan lahan

2. Kemudahan akses menuju tapak

3. Sarana penunjang dalam bidang seni pertunjukan

4. Memiliki sarana dan prasarana/potensi lingkungan yang mendukung keberadaan bangunan pusat seni pertunjukan.

5. Berkarakter budaya 


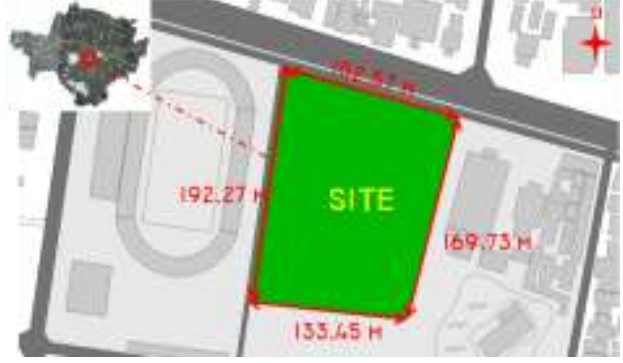

Gambar 1. Lokasi Tapak

Tapak terpilih berada di Jalan Slamet Riyadi, Kecamatan Banjarsari, Kota Surakarta. Jalan Slamet Riyadi memiliki lebar jalan utama satu arah dengan 3 lajur dan lebar \pm 14 meter. Jalan Slamet Riyadi dapat dilalui oleh berbagai jenis kendaraan sehingga didapat GSB (Garis Sempadan Bangunan) selebar 7 meter. Hal ini terkait dengan penyiapan lahan untuk ruang terbuka dan kaitannya dengan BCR (Building Coverage Ratio) 60\% pada kawasan tersebut.

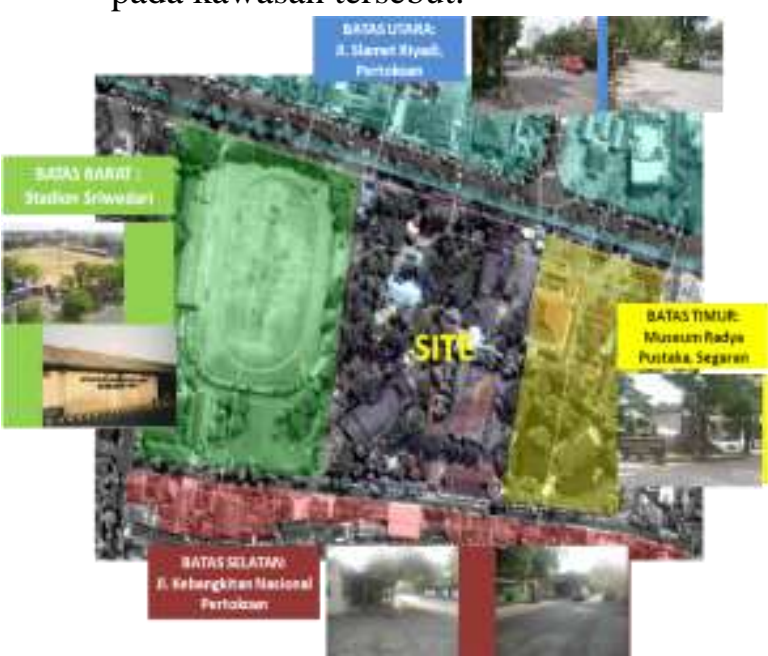

Gambar 2. Batas Tapak

\subsection{Analisa View dan Orientasi}

Analisa view dan orientasi bertujuan untuk menentukan orientasi bangunan Pusat Seni Pertunjukan yang direncanakan 1. Dasar Pertimbangan

a) Sudut pandang dari dalam maupun luar tapak

b) Titik ekspos tertinggi tapak dilihat dari lingkungan.

c) Memaksimalkan potensi view yang ada baik view dalam tapak maupun view tapak di lihat dari luar.
d) Potensi view menjadi salah satu dasar pertimbangan penentuan orientasi massa bangunan.

\subsection{Analisa View}

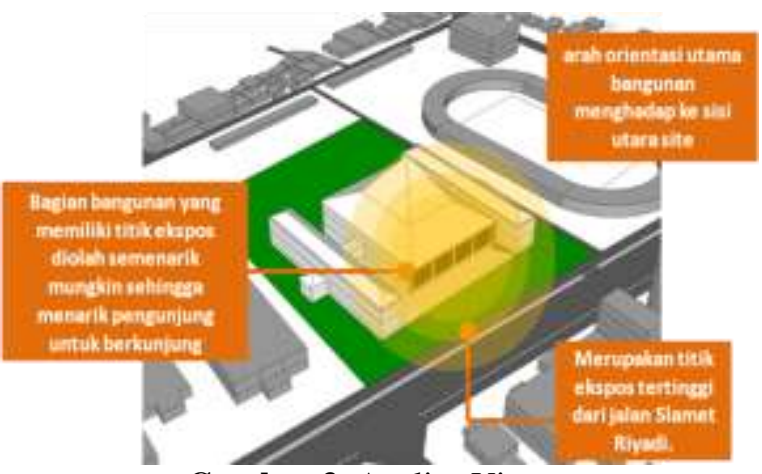

Gambar 3. Analisa View

\subsection{Analisa Pola Tata Massa}

1. Dasar Pertimbangan

a) Menentukan pola tata massa yang ideal untuk bangunan pusat seni pertunjukan.

b) Menentukan pola tata massa yang Eko Kultural

\section{Analisa}

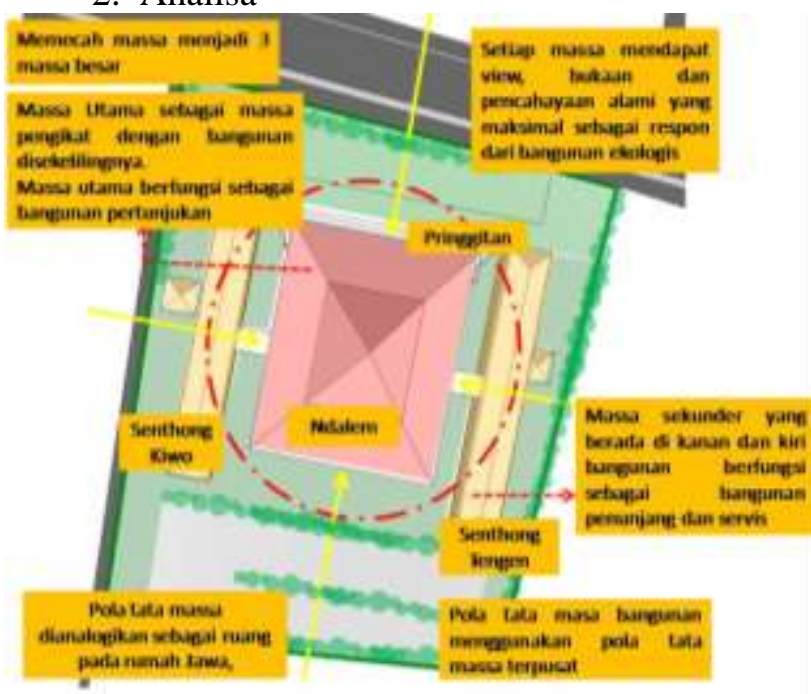

Gambar 4. Analisa Pola Tata Massa

\subsection{Analisa Pemintakatan}

Analisa pemintakatan bertujuan untuk menentukan mintakat (zoning) berdasarkan sifat kegiatan dan keadaan pada tapak.

Dasar pertimbangan: analisis peruangan, analisis pengolahan tapak, pola tata massa. Pada analisa pemintakatan ini memperhatikan persyaratan ruang, 
berdasarkan kelompok kegiatan dan analisis pengolahan tapak.

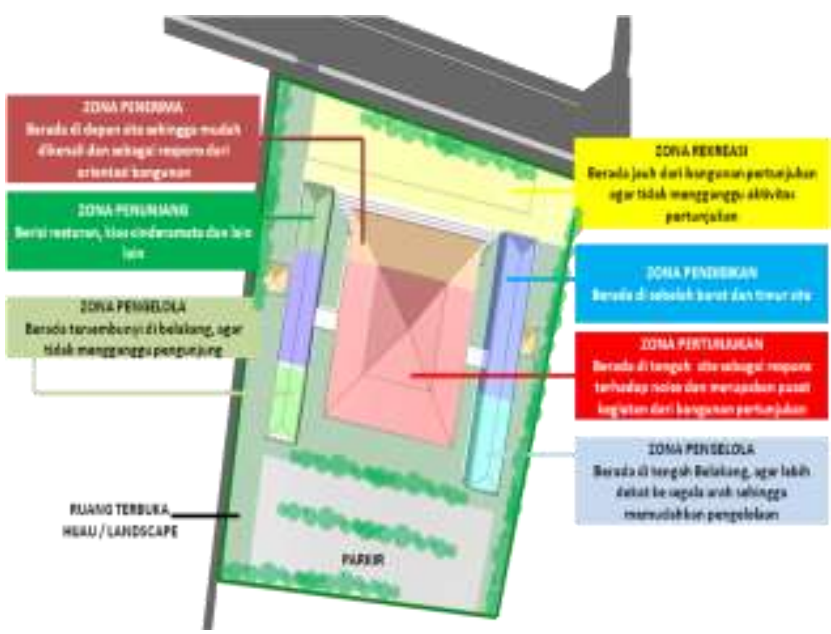

Gambar 5. Analisa Pemintakatan

\subsection{Analisa Bentuk dan Tampilan Bangunan}

3.9.1 Analisa Bentuk Massa

a. Dasar Pertimbangan

1) Massa bangunan yang menerapkan unsur budaya Jawa yang ramah lingkungan

2) Massa bangunan yang menarik/ikonik

b. Analisa

1) Bentuk bangunan yang mengambil bentuk rumah jawa seperti rumah joglo atau limasan.

2) Material, struktur, dan tata massa nya memperhatikan unsur lingkungan

3) Mampu menampilkan sebuah bangunan yang mampu menarik minat pengunjung.

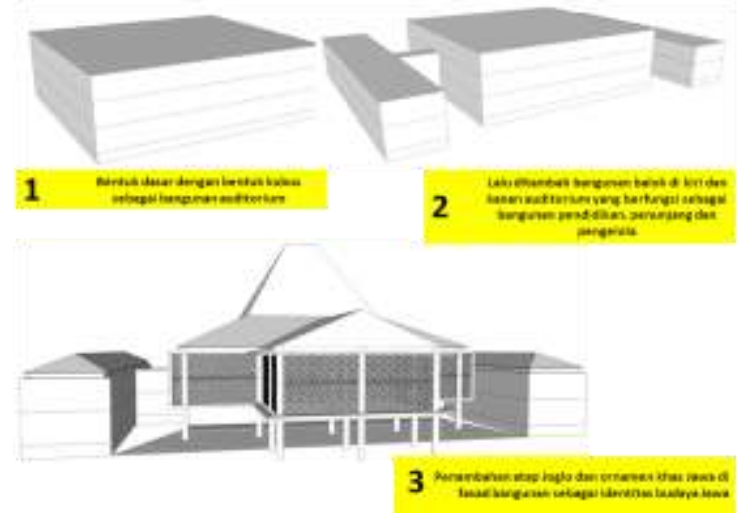

Gambar 6. Analisa Bentuk Massa

\subsubsection{Analisa Tampilan Bangunan}

a. Dasar Pertimbangan

1) Penerapan unsur budaya yang ramah lingkungan.

2) Tampilan bangunan yang menarik dan ikonik.

b. Analisa

1)Dapat menunjukkan unsur budaya yang ramah lingkungan pada tampilan bangunan.

2)Mampu menampilkan sebuah tampilan bangunan yang menarik minat pengunjung.

\subsection{Analisa Ruang}

Salah satu kriteria pada penerapan teori Eko Kultural yang akan diterapkan pada interior ruangan, yaitu menggunakan interior khas Arsitektur Jawa namun tidak melupakan unsurunsur ramah lingkungan. Tentunya material atau warna interior ruangan juga disesuaikan dengan fungsinya masingmasing. Seperti spesifikasi material atau warna interior ruang pelatihan seni berbeda dengan interior bangunan teater namun semua ruang tersebut tetap pada satu garis desain yang sama yaitu Eko Kultural.

a. Dasar Pertimbangan

1) Jenis kegiatan dalam ruang

2) Pemilihan warna ruang

b. Analisa

1) Pemilihan karakter warna sesuai unsur-unsur alam seperti warna coklat dan biru muda.

2) Pemilihan material yang sesuai dengan jenis kegiatan

3) Penerapan interior bergaya Jawa

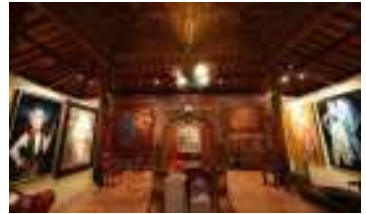

Gambar 7. Interior

(Sumber:http://v2.garudamagazine.com/featur es.php?id=109)

\subsection{Analisa Ruang Pertunjukan}

Tujuan analisis ini adalah untuk menentukan bentuk ruang pagelaran musik yang memenuhi persyaratan 
akustik sehingga dapat mendukung pertunjukan musik, memberi kenyamanan bagi pengguna bangunan serta mempertoleh bentuk yang sesuai dengan bentuk tapak.

Tabel 2. Analisa Bentuk Lantai Pertunjukan

\begin{tabular}{|c|c|}
\hline $\begin{array}{l}\text { Bentuk } \\
\text { Lantai }\end{array}$ & Analisa \\
\hline $\begin{array}{l}\text { Lantai Segi } \\
\text { Empat }\end{array}$ & $\begin{array}{l}\text { (+)Menampung lebih banyak } \\
\text { penonton } \\
\text { (-)Elemen dinding sejajar } \\
\text { mengakibatkan pemantulan } \\
\text { sejajar yang kurang baik. } \\
\text { (-)Penonton paling belakang } \\
\text { tidak dapat mendengar bunyi } \\
\text { dengan jelas }\end{array}$ \\
\hline $\begin{array}{l}\text { Lantai } \\
\text { Bentuk } \\
\text { Kipas }\end{array}$ & $\begin{array}{l}\text { (+)Elemen dinding tidak sejajar } \\
\text { mengakibatkan pemantulan } \\
\text { sejajar yang baik. } \\
(+) \text { Penonton lebih dekat ke } \\
\text { sumber bunyi } \\
(+) \text { Menampung penonton yang } \\
\text { banyak }\end{array}$ \\
\hline $\begin{array}{l}\text { Lantai } \\
\text { Bentuk } \\
\text { Tapal Kuda }\end{array}$ & $\begin{array}{l}\text { (-)Dinding yang dilengkungkan } \\
\text { cenderung menimbulkan gema, } \\
\text { pemantulan jangka waktu } \\
\text { panjang,dan pemusatan bunyi. }\end{array}$ \\
\hline $\begin{array}{l}\text { Lantai Tak } \\
\text { Teratur }\end{array}$ & $\begin{array}{l}\text { (+)Penonton dapat sedekat } \\
\text { mungkin dengan sumber bunyi } \\
\text { (+)Menghasilkan pemantulan } \\
\text { dengan waktu tunda yang } \\
\text { singkat, distribusi secara acak } \\
\text { dan difusi. }\end{array}$ \\
\hline
\end{tabular}

Berdasarkan kelebihan dan kekurangan masing-masing bentuk di atas maka dipilih bentuk kipas sebagai bentuk lantai auditorium.

\subsection{Analisa Sistem Struktur}

Sistem struktur yang diterapkan pada bangunan Pusat Seni Pertunjukan adalah sebagai berikut,

\section{Sub Structure}

Struktur pondasi dipilih pondasi tiang pancang. Pondasi ini biasa digunakan untuk bangunan lebih dari satu atau empat lantai. Pondasi ini lebih tepat digunakan untuk bangunan teater yang berlantai banyak dan menopang atap dan massa yang besar. Sedangkan untuk bangunan pendidikan menggunakan pondasi batu kali karena berlantai rendah.

2. Super Structure

Dikarenakan bangunan pusat seni pertunjukan bukan merupakan bangunan dengan kapasitas lantai yang rendah, dan tidak membutuhkan struktur yang rumit, maka alternatif struktur badan yang dapat digunakan adalah struktur rangka dinding dengan kolom dan balok sebagai pemikul beban.

\section{Upper Structure}

Penggunaan struktur rangka baja lebih efisien dalam penerapan pada bangunan bentang sedang dan lebar. Pelaksanaan pemasangan dan perawatan cukup mudah. Tidak memerlukan banyak kolom untuk menyangga beban atap. Rangka baja juga dapat didaur ulang dan tidak mencemari lingkungan. Selain menggunakan struktur rangka baja juga menggunakan struktur dak beton untuk di beberapa bagian.

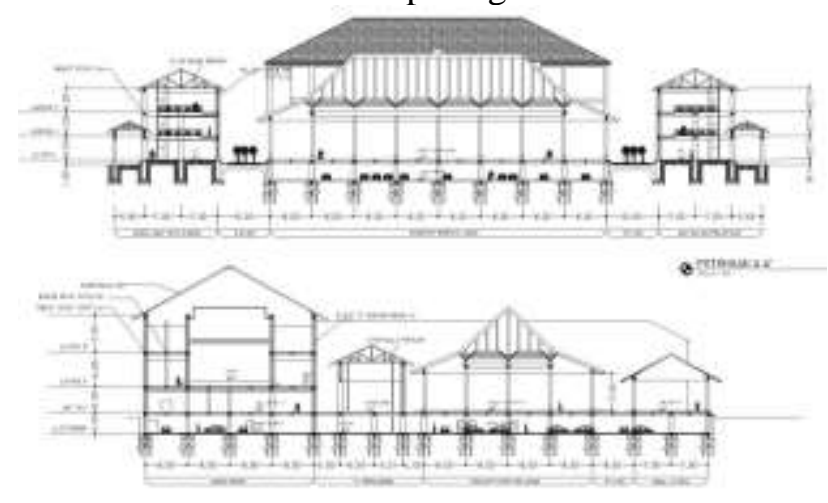

Gambar 8. Potongan

\subsection{Analisa Sistem Utilitas}

1. Jaringan Air Bersih

Terdapat 2 sistem penyediaan air bersih pada bangunan pusat seni pertunjukan yaitu PDAM, air tanah, dan air dari pengolahan limbah.

2. Jaringan Air Kotor

Jaringan air kotor (Black water dan grey water). Sistem pengolahan air 
kotor diarahkan untuk menghindari pencemaran. Air kotor yang dapat di gunakan kembali (grey water) di olah dalam water treatment.

3. Jaringan Listrik

Sumber listrik utama pada bangunan menggunakan sumber dari PLN, dan panel surya sebagai sumber kedua, sedangkan sebagai sumber cadangan menggunakan generator set (genset).

4. Jaringan Komunikasi

Jaringan komunikasi yang akan digunakan menggunakan telkom, intercom untuk hubungan antar ruangan dan loudspeaker untuk komunikasi dengan pengunjung.

5. Jaringan Penanggulan Kebakaran

Untuk menanggulangi bahaya kebakaran, kawasan ini menggunakan cara manual dan otomatis, yaitu penyediaan tabung pemadam kebakaran portable (portable fire extinguisher system) dan sprinkler, diletakkan pada tempat-tempat dan ruangan yang rawan terjadi kebakaran dan penempatannya mudah dijangkau. Untuk didalam ruangan terdapat sprinkler dan tabung pemadam, untuk kebakaran yang terjadi di luar ruangan menggunakan hydrant yang tersedia.

6. Jaringan HVAC

Selain

memanfaatkan penghawaan alami, sistem penghawaan juga menggunakan penghawaan secara mekanis menggunakan AC (air conditioning). Sistem AC yang akan digunakan yakni sistem split untuk ruang pendidikan dan pengelola, dan central untuk ruang auditorium yang berukuran besar.

7. Jaringan Sampah

Sistem jaringan sampah pada bangunan ini dibagi menjadi dua, yaitu sampah dari bangunan dan sampah dapur. Pada pengolahan nantinya sampah juga dibagi lagi menjadi anorganik dan organik, sehingga lebih mempermudah proses daur ulang.

\section{KESIMPULAN (KONSEP DESAIN)}

Permasalahan arsitektural dari perancangan Pusat Seni Pertunjukan di
Surakarta adalah bagaimana merencanakan suatu Pusat Seni Pertunjukan di Kota Surakarta sebagai Wadah Pendidikan Seni dan Hiburan bagi Masyarakat dengan Pendekatan Eko Kultural di mana di dalamnya mampu menampung semua aktifitas seni pertunjukkan daerah, dengan tempat yang representatif, nyaman, serta berbudaya melalui pendekatan Eko Kultural sebagai pendekatan desain arsitektural. Eko Kultural sendiri sebagai konsep pendekatan diwujudkan dalam bentuk fisik, pola tata massa, nilai filosofis, motif ragam hias, penyesuaian terhadap iklim setempat dan penghematan energi. Aplikasi pada bangunan yaitu penerapan bentuk atap Joglo, bentuk fisik yang berarsitekturkan Jawa, penggunaan motif ragam hias khas Jawa, penggunaan pola tata massa rumah Jawa dan material bangunan yang ramah lingkungan. Pada akhirnya hasil yang diperoleh berupa desain dari bangunan Pusat Seni Pertunjukan di Surakarta dengan Pendekatan Eko Kultural.

\subsection{Rencana Tapak}

Lihat lampiran 1

\subsection{Potongan}

Lihat Lampiran 2

\subsection{Perspektif}

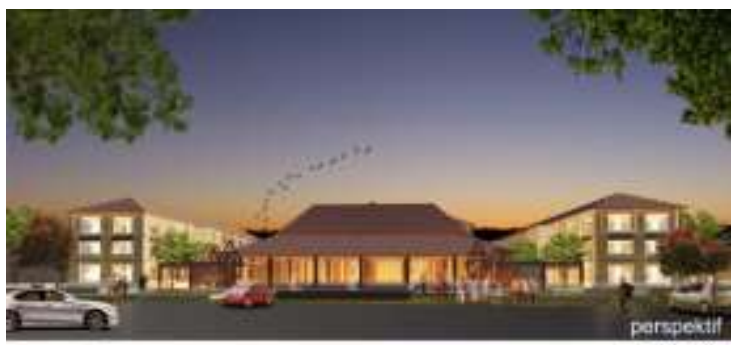

Gambar 12. Perspetif Kawasan

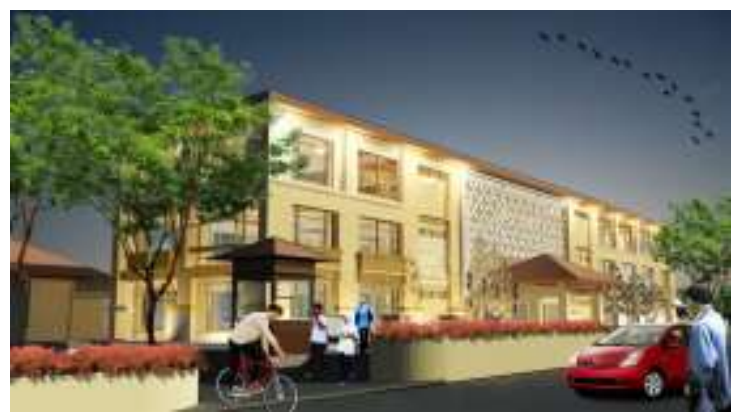


Gambar 13. Perspektif Bangunan Pendidikan

\subsection{Interior}

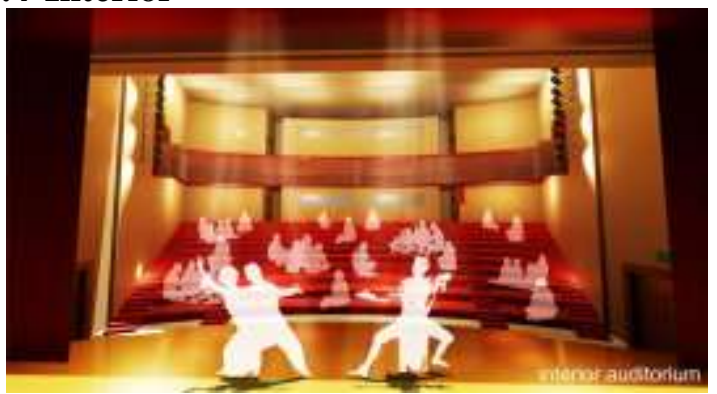

Gambar 14. Interior Auditorium

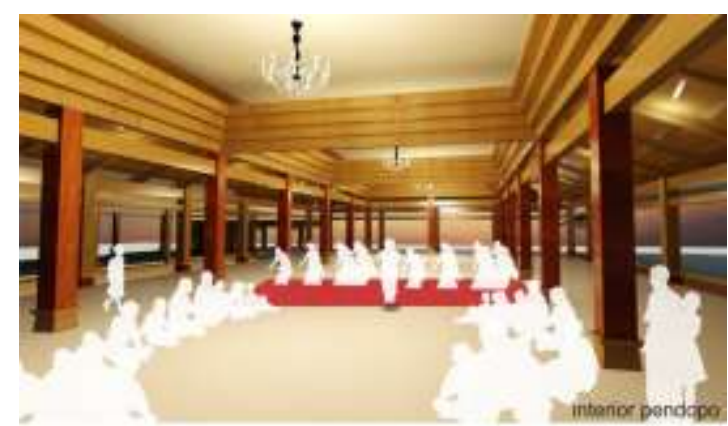

Gambar 15. Interior Pendopo

\section{REFERENSI}

Sedyawati, Sejarah kebudayaan Indonesia: seni pertunjukan dan seni media, 2009

Richard Schenel, 1988, Performance Theory, Routledge

Kamus Besar Bahasa Indonesia, Edisi keempat, 2008, Balai Pustaka

Interior Rumah Jawa dalam http://v2.garudamagazine.com/features. php?id=109) diakses pada 20 Agustus 2014 pukul 20:46 WIB 